Abstracta Iranicacta Iranica

Revue bibliographique pour le domaine irano-aryen

Volume 26 | 2005

Comptes rendus des publications de 2003

\title{
Essays on the Origins of Kurdish Nationalism. Costa Mesa, Mazda, 2003, 234 p.
}

\section{Christine Allison}

\section{(2) OpenEdition}

1 Journals

\section{Édition électronique}

URL : http://journals.openedition.org/abstractairanica/2914

DOI : $10.4000 /$ abstractairanica.2914

ISSN : 1961-960X

Éditeur :

CNRS (UMR 7528 Mondes iraniens et indiens), Éditions de l'IFRI

\section{Édition imprimée}

Date de publication : 15 mai 2005

ISSN : 0240-8910

\section{Référence électronique}

Christine Allison, «Essays on the Origins of Kurdish Nationalism. Costa Mesa, Mazda, 2003, 234 p. », Abstracta Iranica [En ligne], Volume 26 | 2005, document 270, mis en ligne le 15 décembre 2005, consulté le 25 septembre 2020. URL : http://journals.openedition.org/abstractairanica/2914 ; DOI : https://doi.org/10.4000/abstractairanica.2914

Ce document a été généré automatiquement le 25 septembre 2020.

Tous droits réservés 


\title{
Essays on the Origins of Kurdish Nationalism. Costa Mesa, Mazda, 2003, $234 \mathrm{p}$.
}

\author{
Christine Allison
}

1 This important book contains essays by some of the best-known names working in the field and applies academic analysis to an area of study which has been over-frequented by mythmakers, both pro-and anti-Kurdish. The evident disagreement between the editor and a contributor over approaches - Vali finds Hassanpour 'essentialist', Hassanpour criticises Vali's 'coherentism' - is made clear as early as the editor's introductory chapter.

2 The focus of Amir Hassanpour's long chapter is pre-20th century historical and literary sources expressing Kurdish identity, including Sheref Khan Bitlisi, Khanî, and Khoyî. The substantial second section, however, is devoted to criticism of theoretical stance and metatheory. He advocates the use of such terms as 'feudal nationalism' to describe pre-modern Kurdish identity, and critiques Vali's criticisms of the Marxist approaches used in his (Hassanpour's) past work.

3 Abbas Vali's second essay focuses on Kurdish historiography, contrasting 'primordialist', 'ethnicist' and 'constructivist' perspectives. He then considers the works of Muhammad Amin Zaki and Amir Hassanpour ('ethnicist') and Jamal Nebez ('primordialist'), and remarks on the conditions of formation of the modern phenomenon of Kurdish historical discourse.

Martin van Bruinessen's chapter on Ehmedê Khanî's Mem û Zîn provides a critique for contemporary Kurdish readings of the epic, which often claim that Khanî was advocating a Kurdish state, by considering the work in its historical context and Khanî's likely aims. He then considers subsequent uses of the ideas in the work by more modern writers who were instrumental in formulating Kurdish nationalist discourse.

There are two contributions by Hamit Bozarslan. The first, on Kurdish historiography in Turkey, explains (like Vali) that Kurdish history is constructed - 'imagined' - as much as every other aspect of the nation, and is part of the political process. He 
analyses the trends by period: Interregnum (1919-23), establishment of Kemalist rule (1923-28), the decades of silence (1930s-early 1960s), the period of revival (1960s-1980s).

6 Bozarslan's second essay focuses on Kurdish nationalism in Turkey. From 1919-21 the nationalist movement was dominated by urban élites, but from 1923 onwards, especially after the abolition of the Caliphate, the traditional rural élites became dominant; in the first period, nationalists defined themselves as Kurdish in opposition to the Turks, whereas in the second, it was the State (with its broken promises) which was felt to be oppressive, leading to large-scale mobilisation.

7 Nelida Fuccaro's chapter on the Kurdish movement in mandatory Syria, focusing on politics, culture and identity, sheds welcome light on a lesser-known area. The role of Khoyboun and Armenian cooperation is made clear, and the career of the prominent chief Hajo Agha of the Heverkan is used as a bridging device which explains the different phases of development, from separation from Ottoman Turkey to the evolution of Arab nationalism and imminent independence for Syria.

INDEX

Thèmes : 4.5. Histoire des kurdes

\section{AUTEURS}

CHRISTINE ALLISON

Monde iranien - INaLCO 